\title{
ANÁLISE DOCUMENTAL DE IMAGEM: UMA LEITURA DAS CONTRIBUIÇÕES SEMIÓTICAS
}

\author{
DOCUMENTARY IMAGE ANALYSIS: \\ A READING OF SEMIOTIC CONTRIBUTIONS \\ ANÁLISIS DOCUMENTAL DE IMAGEN: \\ UNA LECTURA DE LAS CONTRIBUCIONES SEMIÓTICAS
}

${ }^{1}$ Ana Clara Gatto

1Universidade Estadual Paulista

\section{Correspondência}

1Ana Clara Gatto

Universidade Estadual Paulista

São Paulo, SP

Email: anac.gatto@gmail.com

ORCID: http://orcid.org/0000-0002-6650-4629

Submetido em: 06/10/2017

Aceito em: 13/11/2017

Publicado em: 27/11/2017

JITA: IB. Content analysis (A and I, class.) 
RESUMO: Analisando a imagen como objeto de estudo científico e sendo compreendida como documento, o presente artigo busca realizar uma revisão acerca dos estudos sobre análise documental e análise de conteúdo da Imagem em imagens fotográficas, artísticas e midiáticas, para fins de indexação. A metodologia utilizada será qualitativa com caráter descritivo e objetiva apresentar as principais contribuições na área da semiótica visual. Conclui-se que a análise documental junto com as teorías semióticas, compreende as imagens como documento e, por meio da indexação, torna-o disseminado e recuperado.

PALAVRAS-ChAVE: Tratamento documental. Análise de conteúdo. Iconografia. Imagem. Semiótica.

ABSTRACT: Analyzing the image as an object of scientific study, and being understood as a document, this article seeks to carry out a review about the studies on Documentary Analysis and Image Content Analysis being applied in photographic, artistic and media images, for indexing purposes, carried out by the author Maria del Carmen Agustín LaCruz, being reviewed through six articles dating from 1999 to 2015. The methodology used will be qualitative with a descriptive and objective character to present the main contributions of the author in the area of Visual Semiotics.

KEYWORDS: Document analysis. Semiotic. Content Analyse. Iconography. Visual materials.

RESUMEN: Se analiza la imagen como objeto de estudio científico y como documento, este artículo tiene como objectivo llevar a cabo una revisión de los estudios sobre el análisis de documentos para la indización de su contenido. La metodología fue cualitativa con carácter descriptivo y aquí se presentan las principales aportaciones del campo de la semiótica visual. Se concluye que el análisis de documentos recibe contribuciones de las teorías semióticas, y que la imagen es un documento fundamental para la recuperación de la información.

PALABRAS ClaVE: Análisis documental. Semiótica. Análisis de contenido. Iconografía. Materiales Visuales. 


\section{INTRODUÇÃ̃o}

A comunicação humana, desde seu primórdio, deu-se por meio de símbolos iconográficos. A arte rupestre foi o primeiro método de comunicação visual entre gerações passadas e atuais nos quais eram demonstradas aspectos da vida pré-histórica. Pensando em comunicação como meio de trocar símbolos que são assimilados e compreendidos por um receptor, temos que as informações podem ser derivadas em diversos meios, como os impressos, audiovisuais e iconográficos. A biblioteca como unidade de informação possibilita o acesso a diversos tipos documentais, dentre eles, a imagem. Por mais efêmero que seja seu caráter, a imagem possui alto teor informativo, podendo ser utilizado como fonte de informação.

Dentro da biblioteconomia existem técnicas para a análise e descrição de documentos com o intuito deles serem representados e recuperados. Como primeiro passo, temos a Leitura Documental juntamente com a Análise Documental com o objetivo de identificar os aspectos mais importantes do documento escrito, para atribuir conceitos chaves ou descritores. Estes descritores fazem parte do processo de indexação, tarefa em que são identificados e determinados os assuntos do documento (PIEDADE, 1983) no qual são atribuídos conceitos que os caracterizem e os tornem únicos dentro do acervo (PEROTA, 1997), fazendo uso de vocabulários controlados e palavras-chave que facilitam a armazenagem e o acesso ao material (PAZIN, 1993).

Assim como documentos escritos, as imagens entram no acervo, passando também por um processo de análise e indexação, que segundo os autores Pinto, Meunier e Neto (2008), o processo de indexação, sejam de documentos visuais ou textuais, relaciona-se com processos cognitivos por atribuir conceitos que melhor representem o conteúdo do documento visando sua recuperação. Para que esta atividade seja empenhada com sucesso, é preciso seguir uma estrutura lógica de leitura no qual o documento é analisado por partes para que sejam identificados elementos que traduzam o assunto neles tratados. Do mesmo modo que os textuais, a Análise Documental de Imagem busca apontar seus aspectos mais importantes e representa-los em termos que melhor os definem para fins de armazenagem e recuperação.

A imagem é vista como documento na Ciência da Informação, assim como um texto, representa um contexto histórico utilizando signos icônicos para transmitir e comunicar uma informação verbal através do cenário, expressão corporal dos personagens e objetos presentes. Para entender a noção de imagem, recorremos aos trabalhos dos autores Bléry (1981), Joly (1996), Manini (2002), Boccato e Fujita (2006), Panofsky (2002), Agustín LaCruz $(2006,2010)$ e Barthes (1971).

Pensando na imagem como sistema de signos não-linguísticos, sua análise deve ser tratada por um viés semiótico. Nesse sentido, objetivamos analisar as contribuições da semiótica na teoria de análise da imagem tendo em vista a recuperação da informação. Desta

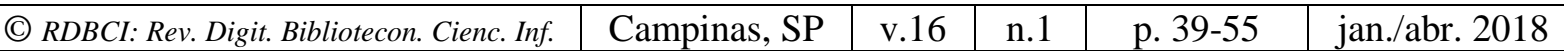


forma, buscou-se revisar as bases conceituais da análise documental de imagem para compreender as teorias semióticas utilizada para indexar documentos imagéticos.

\section{SEMIÓTICA E IMAGEM}

Por semiótica, temos a definição de Blackburn (1997, p. 355) como "o estudo geral dos sistemas simbólicos", tendo como vertentes a Semiótica da Cultura, Semiótica Francesa, Linguística e Semiótica peirceana, no qual será utilizado e analisado neste artigo. Como sistemas simbólicos, a teoria peirceana identifica os elementos chamados de signo, objeto e interpretante. Nesta seção trataremos dos conceitos gerais da semiótica de Peirce (1839-1914) e como a imagem pode ser considerada como signo. Aceitamos, de imediato, a dificuldade de se trabalhar tal tema, dada à complexidade que seria resumir em poucas páginas as diversas linhas da semiótica.

Segundo depreendemos de Peirce (1990), a semiótica seria uma ciência geral dos signos, um tipo de ciência formal dedicada ao estudo da representação. Peirce (1990) definiu signo como aquilo que sob algum aspecto, representa algo para alguém. O primeiro signo criará na mente um signo equivalente a si mesmo. Este signo recebe o nome de interpretante e o que ela representa é o objeto. Apesar de Peirce ter descrito dez tricotomias e sessenta e seis classes de signos, somente três tricotomias serão explicadas por serem suficientes para uma análise da imagem. As três tricotomias são a relação do signo em si mesmo; o signo e seu objeto; e o signo e seu interpretante.

A primeira tricotomia, a relação do Signo em si mesmo divide-se em qualissigno, sinsigno e legissigno. $O$ primeiro diz respeito à qualidade do signo, o segundo a um evento ou coisa tomada como um signo e o último como uma convenção. Como exemplo, temos, respectivamente, uma cor, um cata-vento e as palavras escritas. A segunda tricotomia, que diz respeito ao Signo em relação ao seu Objeto, pode ser dividida em ícone, índice e símbolo. "Ícone é um signo que se refere ao Objeto que denota apenas em virtude de seus caracteres próprios, caracteres que ele igualmente possui quer um tal Objeto realmente exista ou não" (PEIRCE, 1990, p. 52), isto é, ícone são todos os signos que apresentam alguma semelhança com o objeto representado, o objeto real. Índice refere-se ao objeto denotado, sendo assim, o signo é afetado por esse objeto, mas não apresenta semelhança com ele. Sua denotação diz respeito ao sinsigno, no qual reconhecemos os eventos daquele signo sem precisar ver o objeto real que ele se origina. Símbolo refere-se ao objeto denotado, mas diferente do índice, é afetado pelo objeto devido a associações de ideias/convenções. A terceira tricotomia considera o Signo em relação ao seu Interpretante, que não será discutida neste artigo por ser relacionada à Linguística, são divididas em rema, dicente e argumento. Um rema é um signo que para o interpretante pode funcionar como signo que pode ou não ser verificada, como a palavra vermelho. Um dicissigno, ou dicente, é um signo de uma existência real, de um fato, podendo ser correspondente a um enunciado formado por remas. O argumento é um signo de lei, e sendo este um símbolo deve envolver um Símbolo Dicente, chamado de

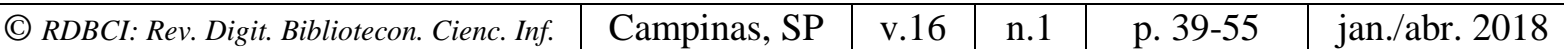


premissa, "pois o Argumento só pode sublinhar a lei sublinhando-a num caso em particular" (PEIRCE, 1990, p. 54), podendo ser exemplificado como um discurso, no qual o parágrafo primeiro tem ligação com segundo que origina o terceiro. Os parágrafos, por exemplo, são constituídos de remas que se tornam um dicente quando são atribuídos significados conforme sua fala e interpretação do ouvinte/leitor.

Os conceitos de signos, objeto e interpretante, bem como as tricotomias do signo de Peirce são fundamentais para compreender a imagem como signo. A imagem, como sabemos, possui diversos significados, como Lalande cita em seu verbete (1962, p. 464-465) no qual a imagem é uma "reprodução, às vezes concreta, outras mentais, que foi percebido, [...] é uma sensação [...] previamente comprovada, um primeiro instinto [...]; representação concreta construída pelas atividades do espírito; combinações pela sua forma, não elementos, resultantes da criação da imaginação; particularmente, uma representação concreta que ilustra uma ideia abstrata" (tradução nossa).

Santaella (2005) diz que a imagem possui três domínios: 1) o domínio das imagens mentais; 2) as imagens diretamente perceptíveis; 3) representações visuais, incluindo nesse domínio desenhos, pinturas, gravuras, fotografias, imagens cinematográficas e televisivas. A imagem pode denominar muitas coisas, dentre elas estão às figuras, estátuas, sombras, fotos, memórias, manchas e até mesmo ideias, também chamadas, respectivamente, de domínio como representações visuais e domínio imaterial (SANTAELLA; NÖTH, 1997). Resumindo, a imagem, sendo mental ou não, é a reprodução de um signo, real ou imaginário, que traduz um conceito, um contexto ou um objeto real.

De acordo com Joly (1996), estudar os fenômenos semióticos significa estudar o modo de produção de sentido, "signo só é 'signo' se 'exprimir ideias' e se provocar na mente daquele ou daqueles que o percebem uma atitude interpretativa" (JOLY, 1996, p. 29). Dessa forma, a semiótica busca categorizar os signos e seus diferentes tipos de especificidade, leis e o processo de significação. As imagens, ao desempenhar uma função sígnica, representam um objeto a um interprete que o reconhece como signo, seu representamen. Segundo Santaella e Nöth (1997) as imagens que se apresentam como semelhantes ao signo são considerados ícones, é um tipo de signo plástico, "um signo completo com expressão e conteúdo próprios. O conteúdo de um signo plástico resulta de cada significado que o observador une às qualidades como forma, cor e textura" (EDELINE et al. apud SANTAELLA, NÖTH, 1997, p. 41).

Após conceituar semiótica peirceana e imagem entendida como signo, devemos examinar a noção de imagem adotada na análise documental. 


\section{IMAGEM E SEMIÓTICA NA ANÁLISE DOCUMENTAL}

Tendo em mente que os documentos imagéticos possuem informações vinculadas, e como objetivo da Ciência da Informação a recuperação e disseminação da informação, as imagens devem passar por um processo de análise, em que podem ser identificados os aspectos intrínsecos e extrínsecos do documento, sendo expressos em pontos de acesso por meio da indexação. Com base na Análise Documental e a semiótica é possível descrever os aspectos mais importantes da imagem e torná-la recuperável. A seguir, relacionaremos as contribuições conceituais da semiótica à análise documental de imagem. Antes, porém, convém destacar o que entendemos por análise documental no âmbito da Documentação.

A Análise Documental ou Documentária tem sua origem na Documentação e pode ser definida como um conjunto de procedimentos que visam expressar o conteúdo dos documentos de forma que os mesmos se tornem únicos e, dessa forma, possibilitando sua recuperação (CUNHA, 1987). Na análise documental de conteúdo trata-se de obter informações relevantes do documento que geram produtos secundários como o índice e resumo. Para isto, é utilizada a indexação, que identifica o conteúdo principal do documento, a classificação que detecta o tema central e o resumo que reduz todo o conteúdo do documento com seus pontos principais seguindo sua mesma estrutura (PINTO MOLINA, 1993).

Para as autoras Boccato e Fujita (2006), a indexação de imagens pode ser baseada em dois conceitos: um baseado no conteúdo que considera a cor, forma e textura; outro baseado nos conceitos nas quais as imagens são identificadas e descritas em termos que elas representam o que possibilitaria um alto nível de análise.

Dentro das imagens temos as ilustrações, mais especificamente as ilustrações que acompanham um texto antigo. Para Agustín LaCruz (2003), o estudo dessas ilustrações tornase um meio para estudo das repercussões sociais analisando-as como meios de expressão que utilizam linguagem icônica para transmitir uma informação, sendo divididas em duas grandes fases: a primeira que recorre na Antiguidade e vai até o final da Idade Média, com as ilustrações nos manuscritos, frequentemente coloridos que eram denominados 'miniaturas'; e a segunda fase que se inicia em torno do século XV com a invenção da imprensa, sendo caracterizada por metade do século com impressões de xilogravura em blocos de madeira. Neste contexto, houve a principal transformação do sistema gráfico utilizado para a transmissão do conhecimento, pois com os processos tipográficos, tornou-se possível a reprodução em grande escala da mesma imagem.

Além dos seus aspectos decorativos, as imagens dos livros se caracterizam por estarem ligadas a um conteúdo do documento. No seu sentido mais abrangente, as ilustrações constituem meios de expressão visual que podem facilitar a compreensão de uma ideia ou conceito, tendo como objetivo "traduzir" o conhecimento através de aspectos icônicos. A

\begin{tabular}{|l|l|l|l|l|l}
\hline (C) RDBCI: Rev. Digit. Bibliotecon. Cienc. Inf. & Campinas, SP & v.16 & n.1 & p. 39-55 & jan./abr. 2018 \\
\hline
\end{tabular}


função da imagem, em primeiro lugar, é de caráter informativo, seja documental ou interpretativo, com a finalidade de deixar a informação mais clara tornando, dessa forma, os personagens, a natureza e os objetos retratados linguisticamente mais fáceis de serem identificados. Além disso, as ilustrações cumprem a função de divulgar a arte pictórica mediante os meios de reprodução mecanizados.

Este aspecto leva a estender a concepção de ilustração para um papel cognitivo por relacionar a visualização do verbal com o objetivo de facilitar e enriquecer sua compreensão. Contribuem para organizar, estruturar e ancorar a informação textual favorecendo sua assimilação por parte do receptor. Sendo assim, traduz o processo subjetivo, a abstração das ideias em informação. A ilustração utiliza códigos icônicos para transmitir e comunicar uma informação verbal, constituindo sua utilização no texto como aumento da eficácia no processo comunicativo, utilizando-se de recursos paralinguísticos que os humanos utilizam na comunicação interpessoal, como a entonação, o olhar, a expressão corporal, a gesticulação, as vestes e a postura.

No primeiro momento de análise para a descrição, é preciso reconhecer os diferentes dados representados, sejam eles formas, número de figuras, gestos, a posição dos personagens, os objetos, e se tratando de livros, os capítulos, com o intuito de gerar uma interpretação na qual cada elemento ganha um significado artístico e histórico.

Pensando nas imagens que não são acompanhadas de um texto, mas que possuem seu próprio discurso que pode ser analisado temos as obras pictóricas, que podem ser exploradas tanto em questões documentais quanto informativas. Os objetos estéticos representados que compõem este tipo de imagem são suscetíveis de serem analisados como um enunciado com o propósito de serem descritos para sua recuperação. Seu discurso pode ser analisado segundo seu contexto de produção, emissão e recepção, além das funções comunicativas que desenvolve e os códigos usados para sua representação. Através de uma obra, principalmente um retrato, é possível identificar elementos simbólicos que definem uma época e exalta valores de uma sociedade e cultura específica.

A dificuldade em analisar esse tipo documental se dá em razão dos elementos não se apresentarem de forma linear, mas através de um emaranhado de concepções simbólicos que se diferem em interpretações do receptor, levando em conta suas ideologias e conhecimentos. Por meio de representações abstratas que refletem um sistema político, econômico e social que sofreram um processo de associação sob formas simbólicas e representações personificadas, as imagens pictóricas são um dos meios mais eficazes para manter a ligação entre as abstrações e a realidade de uma determinada sociedade. Desta forma, estas imagens materializam conceitos sociais, políticos, culturais e filosóficos através de pessoas que se transformam em informações por meio de gestos, vestimentas e atributos simbólicos determinados. 
Para Agustín LaCruz (2006), a decodificação pode ser analisada em três níveis sucessivos: num primeiro momento devem-se estudar os contextos de emissão e recepção, em seguida, analisar a imagem como um processo de transferência de conhecimentos no que se refere as informações transmitidas por meio de pessoas, objetos, ações e eventos e analisar a imagem como um sistema de signo que ultrapassa a própria imagem e se relaciona com questões concretas, como a política, sistema ideológico e econômico da cultura representada.

Nesse sentido, a Semiótica inclui as obras artísticas como seu objeto de estudo entendendo a mesma como um sistema de significação cujo signo mantém uma relação arbitrária entre um significante plástico e um significado cultural. Por signo, neste caso, temos a definição de um sistema arbitrário composto por um significado e significante proposto por Saussure e uma relação triádica composta pelo signo, objeto e interpretante de Peirce. A Semiótica é aqui usada para reconstruir aquilo que se projeta através da imagem e como seu sentido é organizado, isto é, relatar o que o autor não disse, mas que sua obra enuncia de forma explícita.

Quando analisados todos os sistemas que compõem a ordem do cenário, pessoa e objetos, o significado da obra pode ser organizado e verbalizado. Para isto, utilizam-se contribuições tanto da ciência da documentação, tornando a imagem um documento que possa ser recuperado, como pela história da arte que utiliza técnicas históricas e a iconografia, estudo feito por Panofsky (2002) que analisa a imagem através de três níveis de significação.

Para a documentação, a imagem é um documento indexável, e para tanto observa os aspectos mais importantes do documento com o intuito de criar descritores que representam seu conteúdo. Neste caso, é necessário fazer uso da história da arte em que são identificados signos icônicos num primeiro momento, analisando o cenário e os objetos que o compõem para, em seguida, atribuir significantes culturais e estabelecer um contexto e ideologia, que pode ser representado por meio de palavras-chave, podendo, desta forma, recuperar essa informação visual.

Panofsky definiu três níveis de significação, sendo o pré-iconográfico com a identificação de todos os objetos que compõem o cenário para, em seguida, o nível iconográfico atribuir significados concretos a estes objetos e a iconologia que confere elementos simbólicos como manifestações religiosas, políticas. Para estas duas últimas análises, é necessário um conhecimento prévio do profissional que é adquirido e aperfeiçoado através do tempo.

A imagem não constitui somente de um tipo de representação icônica que utiliza elementos culturais e históricos como meio de expressão e de comunicação, mas seria caracterizada como um tipo documental específico, a imagem publicitária, por exemplo, constitui de um mecanismo de comunicação de massa com maior capacidade para intervir nos sistemas de pensamento da sociedade e da cultura contemporânea. Além de que estas 
imagens constituem de um grande espaço visual onde é possível observar significações relevantes à natureza cultural, ideológica, estética, social, econômica e política. Em particular, as imagens publicitárias constituem um interessante âmbito de estudo pela riqueza significativa e sua intencionalidade proativa, possui uma capacidade de vender um produto, serviço ou ideia uma vez que se utiliza de diferentes recursos estéticos para sugerir emoções e sentimentos que estimulam o consumo.

Para sua análise, o propósito inicial é o de descrever sua mensagem iconográfica dividida em fases como a determinação do conteúdo e a representação documental. Para Agustín LaCruz (2010) consiste em analisar três planos de significação, sempre consciente do tema, gênero, estilo e contexto. Os três planos são caracterizados como: descrição, que caracteriza de forma objetiva os seres e objetos representados, incluindo aqui dados físicos como idade, gênero, expressões e gestos; a identificação que individualiza os temas representados através dessas pessoas e objetos reconhecidos; e a interpretação, que deve levar em conta a intencionalidade do criador, o ambiente histórico-cultural, seu alcance e o propósito da propaganda.

Barthes (1977) analisou a propaganda de uma marca de macarrão, Panzani, com identificação do pacote com o produto, tomates, cogumelos uma lata, pimentões e alhos em um fundo vermelho. Para o teórico, existem três mensagens que essa propaganda pode perpassar: 1) uma linguística, em que é identificada pelo nome do produto sua origem, no caso, italiana, que nos remete a uma imagem de "italinicidade", juntando o aspecto conotativo com o denotativo; 2) em seguida, temos a mensagem icônica, recorrendo a dois valores, o produto ser fabricado com produtos frescos e da preparação, que remete a algo doméstico; e 3) constitui os objetos reais da cena e seus significantes e o significado da imagem, sendo definida como "a relação entre o significado e o significante quase tautológica, envolvendo um certo arranjo na fotografia [...]” (BARTHES, 1977, p. 154) (tradução nossa).

Pensando no aspecto linguístico, a mensagem que a marca quer transmitir é a de que "comprar para você" é o oposto de estocar alimentos. Com os pimentões e os tomates, que juntos levam as cores vermelho, amarelo e verde, as cores da bandeira italiana, remetem ao significado de "italinicidade", que também é exaltado pelo fato do produto ser uma massa, remetendo à culinária italiana. Outros signos que podem ser identificados são os diferentes objetos que remetem à culinária, em que a Panzani é um alimento balanceado e a lata que identifica que são usados somente produtos naturais. Com estes signos, podemos notar o significado cultural da típica comida italiana.

$\mathrm{Na}$ análise da imagem publicitária, consideramos os diferentes léxicos, ou seja, um plano simbólico (da linguagem) que corresponde a um conjunto de práticas e técnicas, gerando diferentes leituras de uma mesma imagem, chamada de idioleto de uma pessoa, sendo definida por Jota (1976) como um conjunto de hábitos linguísticos considerados

\begin{tabular}{l|l|l|l|l|l|}
\hline (C) RDBCI: Rev. Digit. Bibliotecon. Cienc. Inf. & Campinas, SP & v.16 & n.1 & p. 39-55 & jan./abr. 2018 \\
\hline
\end{tabular}


determinantes de certa época. Dessa forma, a imagem, em sua conotação, é constituída de vários signos variantes do idioleto, não prejudicando suas variadas leituras, sendo que "a linguagem é composta de idioletos, léxicos e sub-códigos” (BARTHES, 1977, p.160) (tradução nossa).

Barthes (1977) conclui que no sistema total da imagem, temos duas funções: um lado de condensação paradigmática no nível conotativo (símbolos); por outro lado, temos o fluxo sintagmático, no nível da denotação, como sendo próximo da fala, sendo um "discurso icônico" o que "naturaliza" os símbolos. Para fins de documentação, Agustín LaCruz (2010) concluiu que a descrição precisa conter o autor criador, a agência, o anunciante, produto, slogan, data, a estratégia argumentativa e os descritores semânticos.

Como última análise, temos a imagem fotográfica, na qual a dificuldade começa pelo fato dela apresentar uma realidade de formar concreta, desta forma, necessitando de uma habilidade de abstração das palavras, sendo que possuem uma característica própria, que segundo Agustín LaCruz (2014) é chamado de semanticidade, isto é, representam algo que passa por alguém que a reconhece. Concebendo a fotografia como um fragmento de algo concreto em um suporte físico que pode ser reconhecida como uma modalidade da comunicação visual que utiliza uma representação plástico-simbólico para gerar uma representação visual reconhecida pelos receptores é, portanto, um suporte de comunicação entre épocas, pessoas e lugares. Para Gastaminza (1999, p. 113) "a fotografia apresenta o aspecto de pessoas, objetos, lugares ou situações de uma maneira mais clara, unívoca, rápida e exata que uma informação verbal descritiva sobre a mesma" (tradução nossa).

Para ler a fotografia e a informação, primeiramente deve estar ciente da polissemia e da característica indiciária do signo fotográfico que remete a um registro com informações nele contido. Dentro da Ciência da Informação, a fotografia é inserida na dinâmica dos fluxos de informação por estar sujeita à reprodução, ressaltando que a fotografia é composta em três vieses: a linguagem, registro e informação (LIMA; MURGUIA, 2008).

A relação que se tem entre fotografia e linguagem parte do pressuposto de um código mediador entre o receptor e o emissor que gera um processo de comunicação, sendo assim, de circularidade. Por emissor, temos o fotógrafo e receptor as diferentes demandas na leitura da imagem. Nesta linguagem, não estaria circunscrita somente as próprias produções fotográficas, mas o reflexo acerca dessa produção que materializa em um sentido na mente do receptor. Pensando na semiótica proposta por Peirce, a imagem fotográfica, por se assemelhar com o real, é um dicissigno, ou seja, mantêm relação de existência real com o objeto retratado, que é reconhecido, pois o intérprete tem conhecimento deste objeto anteriormente à imagem (SHAEFFER, 1996 apud LIMA; MURGUIA, 2008). Contudo, ainda em Peirce, quando relacionamos os traços do objeto referencial de uma fotografia, estamos destacando os ícones, os quais só funcionam como fotografia no caso de remeterem ao objeto, isto é, converte-se em índice antes mesmo de transferir mensagem no âmbito do dicissigno.

\begin{tabular}{l|l|l} 
v.16 & n. 1 \\
\hline
\end{tabular}
p. $39-55$ jan./abr. 2018 
A fotografia como signo indiciário vinculado à ideia de registro retomaria a noção de informação. A informação, pensada no viés da fotografia, se torna objeto da ciência da informação por registrar em um suporte, que se converte em cultura simbólica, que está vinculada à sociedade. Assim, a imagem fotográfica seria "uma construção social de sujeitos históricos em condições espaciais e temporais determinadas" (LIMA; MURGUIA, 2008, p.10).

Para compreender seu significado devem ser levados em conta seus aspectos sociais, históricos e culturais dentro de uma perspectiva diacrônica, voltado aos fatos dentro de uma evolução do tempo, e sincrônica estudando o evento no período em que ele ocorreu, além de considerar o olhar do fotógrafo e do receptor e os elementos que compõem esse processo comunicativo.

Atualmente, a imagem fotográfica é vista como um objeto de estudo interdisciplinar, como no estudo com enfoque histórico em que é vista como fonte de informação e documento histórico. No enfoque filosófico centra-se nos estudos das relações da imagem com a linguagem verbal e seus aspectos étnicos. De um ponto de vista artístico, são analisadas as formas visuais e seus significados. A antropologia estuda a capacidade de a fotografia ser utilizada como instrumento capaz de descrever e analisar a realidade humana. A sociologia observa na fotografia um meio para estudar a sociedade e a cultura. Por fim, o estudo semiótico valoriza a imagem enquanto signos icônicos e o enfoque informativodocumental entende a fotografia como evidência e como fonte de informação recuperável.

Para a indexação de imagens estáticas, Shatford Layne (1994) destaca quatro categorias gerais: biográficos; exemplificativos; de relacionamento e; de assunto, sendo esta o reflexo do que as pessoas pensam, tornando, na opinião da autora, a categoria mais importante, mas a menos objetiva. Para a categoria assunto na imagem é necessário pensar em três atributos: 1) DE e SOBRE, sendo a diferença entre o significante e o significado (exemplo: a imagem DE alguém chorando pode ser SOBRE a tristeza), "portanto, quando a imagem é DE, o aspecto mais provável é que a figuração seja concreta e objetiva; quando uma imagem é SOBRE, há mais propensão de ser abstrata e subjetiva" (SHATFORD LAYNE, 1994 p. 584). O DE é vinculado à percepção e descrição do que se observa na imagem, sendo num nível básico, o SOBRE exige um conhecimento para descobrir seu significado; 2) temos que a imagem pode ser genérica ou específica, onde respectivamente, podemos descrever a imagem como algo sem aprofundamento como podemos esclarecer o que é esse objeto (por exemplo uma ponte, podemos descrevê-la somente como uma ponte ou podemos especificar como a ponte do Brooklyn); 3) e no terceiro aspecto, a imagem pode ser classificada em quatro facetas: tempo, espaço, atividades e eventos e objetos, podendo ser animadas ou inanimadas (PATO, 2014). E para traduzir ou transcodificar a imagem, a autora Bléry (1981 apud AMARAL, 2009) categoriza cinco questões fundamentais: quem?, como?, o quê?, onde? e quando? 
Para Gastaminza (1999), quando consideramos a imagem como objetos de análise documental têm que considerar aspectos como os atributos biográficos. A fotografia tem uma origem, sendo importante identificar o artista, a escola a qual pertence e o título da imagem e atributos temáticos, sendo o significado da imagem, seu tema, "uma coisa é o que aparece na imagem, o que se vê, concreto e objetivo, e outra o que a imagem sugere, aquilo sobre o que a imagem trata, abstrato e subjetivo" (GASTAMINZA, 1999, p. 122) (tradução nossa).

Pensando na descrição da imagem fotográfica, temos dois aspectos importantes, a questão da informação lateral e a expressão fotográfica. A informação lateral é aqui entendida como o que a imagem mostra os significados que o documentalista atribui àquele documento, os conhecimentos adquiridos com o tempo, que não podem ser influenciado pela legenda, podendo causar equívoco e uma distorção da ideia original do fotógrafo, sendo necessária uma análise mais detalhada (AMARAL, 2009).

A expressão fotográfica seria como a imagem mostra algo de determina maneira, aqui analisando as características do fotógrafo como o enquadramento, luz, ótica da lente e a disposição dos objetos, animais ou pessoas na fotografia, "os descritores da 'expressão fotográfica' - quando designam enquadramentos e posições da câmera - informam muito mais do que simples questões técnicas, pois determina o quanto os detalhes dos personagens podem ser vistos [...] e o quanto se pode ver do ambiente no qual os personagens se encontram [...]" (SMIT, 2011, p. 275-276).

A expressão fotográfica é também abordada por Manini (2002) como dimensão expressiva, que englobam todos os aspectos referentes à técnica empregada na fotografia. Para a autora, considerar a dimensão expressiva na análise documental de imagens está no fato de que é um ponto decisivo na escolha de uma fotografia quando um conjunto de imagens é recuperado em um sistema de informação.

Em síntese, dentro de um sistema de informação a imagem possui características próprias e representam iconograficamente a realidade. Um fato histórico pode ser evidenciado iconograficamente por uma imagem, pintura, desenho ou fotografia, tornando possível o estudo dos contextos sociais, econômicos, históricos e culturais.

\section{CONSIDERAÇÕES FINAIS}

Documentos icônicos, como vistos, possuem significados próprios e diferentes dos documentos textuais, mantendo uma relação com códigos ideológicos e comunicam ideias sem usar a linguagem oral tornando-se independentes. A recuperação de um documento textual implica em analisar seu conteúdo, e das imagens, em identificar seus ícones e significados. 
Aprendemos a ler imagens quando aprendemos a falar, relacionando as palavras com as representações iconográficas. A busca de sentido está relacionada com a capacidade e atitudes do leitor. Para entender o significado global de uma imagem, o receptor considera uma sequência de atos semânticos que compreendem seis etapas, segundo Agustín Lacruz (2014): 1) competência iconográfica: consistem na observação e identificação de formas visuais simples como animais e pessoas; 2) competência narrativa: baseado na experiência visual, o leitor consegue estabelecer relações entre as pessoas, animais e o cenário; 3) competência estética: o leitor atribui sentido dramático segundo suas próprias experiências simbólicas e estéticas; 4) a competência enciclopédica: baseando na sua experiência cultural e seus próprios conhecimentos, o leitor identifica valores e relações relevantes com outras informações; 5) competências linguísticas-comunicativas: capacidade do leitor de elaborar preposições linguísticas com quem comunica e expressa o conteúdo da imagem; e a 6) competência modal: com sua experiência espaço-temporal o leitor compreende a imagem como uma representação de um espaço e tempo determinado.

As seis etapas propostas acima, embora se tratando de diferentes tipos imagéticos, podem ser relacionadas com os níveis de significação de Panofsky (2002). Pensando que o nível pré-iconográfico reconhece figuras, temos que as competências iconográficas e narrativas possuem o mesmo objetivo, o de identificar as representações de pessoas e animais e atribuir, ainda que no estágio inicial, uma relação entre esses símbolos. O nível iconográfico, com o reconhecimento mais aprofundado de quem ou o que está sendo retratado está em sintonia com a competência estética e enciclopédica, no qual são configurados em um determinado contexto, precisando das competências linguísticascomunicativas para expressar as simbologias e a competência modal, assim como a iconologia, para identificar exatamente o espaço e tempo dos objetos apresentados.

A dificuldade em analisar as imagens, como cita Agustín LaCruz (1999) é que elas não são separadas como nos textos, não é possível observar primeiro as cores, depois os objetos e os contrastes, é preciso analisar ela como um todo, o que pode gerar ambiguidade, sendo que as imagens utilizam tanto de realidades concretas como sensoriais que são interpretadas por receptores de forma diferente. Além de que, as imagens transmitem emoções diferentes para cada pessoa. Por tratar de um documento com diferentes significados, ela não possui uma linguagem exata, ela representa ideias e conceitos que são medidas pela relação entre os significantes e significados, sempre se referindo ao contexto.

Apesar de ser estruturada como um todo, Agustín LaCruz (2014) separa a imagem em códigos de diversas naturezas como espaciais, de luz, cor, estenográficos, gestuais, indumentários, tornando possível uma análise estratificada desses códigos que constituem uma boa estratégia de exploração. Temos como código espacial todo o plano que a imagem mostra como uma pessoa/objeto/animal dentro de um cenário, o código gestual é uma expressão simbólica podendo ser tanto corporal como facial. O indumentário refere-se às vestimentas, que representam as questões sociais, culturais, políticas e ideológicas, como no

\begin{tabular}{l|l|l|l|l|l|}
\hline (C) RDBCI: Rev. Digit. Bibliotecon. Cienc. Inf. & Campinas, SP & v.16 & n.1 & p. 39-55 & jan./abr. 2018 \\
\hline
\end{tabular}


caso das obras pictórcias, o código escenográfico indica, através dos objetos e sua distribuição no espaço, um meio de descoberta do status social, valores e concepções do mundo, ponderando o valor das personagens e suas ações, possibilitando a identificação do acontecimento representado com o âmbito geográfico e cronológico concreto, sugerindo, também, aspectos emocionais. A luz e a cor são características subjetivas que conotam sentimentos e são usados para atribuir harmonia e equilíbrio na imagem.

A análise de Barthes (1977) da propaganda das massas Panzani associa-se com as divisões dos códigos de Agustín LaCruz (2014) por proporcionar um primeiro olhar pelo o que a imagem apresenta, assim como no código espacial. Desta forma, o código gestual é a observação de como os alimentos estão organizados no espaço, passando para o indumentário quando o valor de "italinicidade" torna-se claro. No caso da publicidade, as cores e luz ressaltam a culinária italiana e a noção de alimentos aprazíveis, conotando os sentimentos que Barthes identificou como mensagens linguísticas, de produtos frescos e preparação caseira.

No caso da imagem fotográfica, podemos dividir em quatro passos, sendo o primeiro a identificação dos aspectos iconográficos como as pessoas e objetos que compõem o cenário, o segundo é criar uma narração, ou seja, atribuir uma "ação" ao que está sendo visto para em seguida conceder sentimentos perante a estética da foto. $O$ último passo é buscar a autoria da foto, onde ela foi publicada, em qual contexto, a data para assim descrever seu contexto e fazer sua projeção em âmbito global.

Como resultados das reflexões, consideramos que os principais conceitos semióticos e semiológicos a contribuírem com a análise documental de imagem são: tendo signo como tudo o que é passível de interpretação e subjetividades, as imagens são compostas por sistemas de signos, pois são formadas pela tricotomia ícones, índices e símbolos, temos que elas remetem ideologias, histórias e contextos. Essa representação se dá por meio dos ícones que mantém ligação de semelhança com o objeto real, como as pessoas, os animais e os objetos. Quando nomeados, ou seja, quando reconhecidos como elementos reais - nome da pessoa, animal exato, objeto como parte de um todo - , quando identificado os vestígios da realidade, assim como uma data exata, temos o que chamamos de índice. Os símbolos são os signos convencionados, sendo assim, o conjunto que compõem toda a imagem recebe um significado único para cada sociedade, determinada pelos os aspectos culturais.

Como foi visto, o trabalho teve como objetivo a análise das contribuições semióticas na análise documental de imagem, nesse sentido, consideramos que o elenco de conceitos indicados anteriormente atende o propósito estabelecido. De qualquer forma, para uma análise mais completa dos documentos iconográficos, é necessário um conhecimento prévio, tanto cultural como histórico, e identificar os aspectos simbólicos que cada elemento atribuiu ao significado final que o fotógrafo ou pintor quis retratar. Sendo assim, por se tratar de um documento com diferentes significados por representar ideias e conceitos, ela não possui uma linguagem exata, mas são medidas pela relação entre os significantes e significados, sempre 
focando no contexto para uma descrição mais completa.

Tendo este artigo focado em uma pequena parcela dos estudos semióticos, para uma pesquisa mais aprofundada é necessário o estudo detalhado dos diferentes elementos sígnicos, tanto da semiótica peirceana como das outras vertentes, tais como semiótica da cultura e semiologia, além dos métodos de análise da imagem utilizados por diferentes autores e com contribuições ao campo da ciência da informação.

\section{REFERÊNCIAS}

AGUSTÍN LACRUZ, María Del Carmen. El análisis de contenido y la representación documental de las imágenes pictóricas: una investigación desarrollada sobre los retratos de Francisco de Goya. In: ENCONTRÓ NACIONAL DE PESQUISA EM CIÊNCIA DA INFORMAÇÃO, 6., 2010, Marília. Anais ... Marília: ENANCIB, 2010. 1-12.

AGUSTÍN-LACRUZ, María Del Carmen . El análisis documental de contenido de las ilustraciones del libro antiguo., 2003 In: Comercio y tasación del libro antiguo: análisis, identificación y descripción. Prensas Universitarias de Zaragoza, p. 81-116. Disponível em: <http://eprints.rclis.org/14353/>. Acesso em: 07 jun. 2017.

AGUSTÍN-LACRUZ, María Del Carmen. Funciones retóricas en la fotografías publicitárias: un modelo de análisis orientado hacia la representacíon documental. Estudios de información, documentación y archivos, Espanha, p. 11-23, 2014. Disponível em: < https://www.academia.edu/8519895/Funciones_ret\%C3\%B3ricas_en_las_fotograf\%C3\%AD as_publicitarias_Un_modelo_de_an\%C3\%A1lisis_orientado_hacia_la_representaci\%C3\%B3 n_documental >. Acesso em: 07 jun. 2017.

AGUSTÍN-LACRUZ, María Del Carmen. La lectura de las imágenes fotográficas orientadas hacia la representación documental. Encontros Bibli: revista eletrônica de biblioteconomía e ciencia da informação, v. 20, n.esp. 1, p. 55-88. 2015. Disponível em: < https://periodicos.ufsc.br/index.php/eb/article/viewFile/15182924.2015v20nesp1p55/28639>. Acesso em: 07 jun. 2017.

AGUSTÍN LACRUZ, María del Carmen. Metodología para la indización de documentos no textuales: algunas precisiones a propósito de lós documentos gráficos y audiovisuales. In: ENCONTRO ISKO, 3., Zaragoza. Resumo... Zaragoza: F. J. García Marco, 1999. P. 145159.

AGUSTÍN LACRUZ, María del Carmen. O conceito de "texto artístico" e sua relevância para as ciencias da documentação. Brazilian Journal of Information Science, v. 0, n. 0, p. 16-49, jul/dez. 2006.

AMARAL, Lara. A importância do tratamento intelectual das fotografias visando à recuperação da imagem. 2009. 143 f. Dissertação (Mestrado) - Curso de Ciência da Informação, Biblioteconomia e Documentação, Universidade de São Paulo, São Paulo, 2009.

\begin{tabular}{l|l} 
v. 16 & $\mathrm{n} .1$
\end{tabular}
p. $39-55$ jan./abr. 2018 
BARTHES, Roland. Elementos da semiologia. São Paulo: Cultrix, 1977.

BLACKBURN, Simon. Dicionário Oxford de filosofia. Rio de Janeiro: Jorge Zahar, 1997.

BOCCATO, Vera Regina Casari; FUJITA, Mariângela Spotti Lopes. Discutindo a análise documental de fotografias: uma síntese bibliográfica. Cadernos BAD 2, Lisboa, v. 12, n. 2 , p. 84-100, jul/dez. 2006. Disponível em:

<http://apbad.pt/CadernosBAD/Caderno22006/VRCBoccatoMSLFujitaCBAD206.pdf>. Acesso em:20 jun. 2016.

CUNHA, Isabel Maria Ribeiro Ferin. Análise documentária. In: (Coord.) SMIT, J. W. Análise documentária: análise da síntese. 2 ed. Brasília: IBICT, 1987. Cap 4. p. 40-63.

GASTAMINZA, Felix del Valle (Ed.). Manual de documentación fotográfica. Madrid: Sintesis, 1999.

JOLY, Martine. Introdução à análise da imagem. 6. ed. Campinas: Papirus, 1996.

JOTA, Zélio dos Santos. Dicionário de linguística. Rio de Janeiro: Presença, 1976.

LALANDE, Andre. Vocabulaire technique et critique de la philosophie. 9 ed. Paris: Boulevard Saint-Germain, 1962.

MANINI, Miriam Paula. Análise documentária de imagens. Informação \& Sociedade, Paraíba, v. 11, n. 1, p.1-5, 2001. Disponível em:

<http://www.ies.ufpb.br/ojs/index.php/ies/article/view/313/236>. Acesso em: 16 fev. 2016.

LIMA, Maria de Lourdes; MURGUIA, Eduardo Ismael. Fotografia e informação. In: ENCONTRO NACIONAL DE PESQUISA EM CIÊNCIA DA INFORMAÇÃO, 9. Anais... São Paulo: USP, 2008. Disponível em:

<http://enancib.ibict.br/index.php/enancib/ixenancib/paper/viewFile/3014/2140>. Acessado em: 38 de jun. 2017.

PANOFSKY, Erwin. Iconografia e iconologia: uma introdução ao estudo da arte da renascença. In: PANOFSKY, E. Significado nas artes visuais. 3. ed. São Paulo: Perspectiva, 2002. Cap. 2. p. 47-65.

PATO, Paulo Roberto Gomes. Ícone, índice e símbolo, fundamentos para ler e organizar a informação em imagens. In: ENCONTRO NACIONAL DE PESQUISA EM CIÊNCIA DA INFORMAÇÃ O, 15. Belo Horizonte: Minas Gerais, ENANCIB, 2014.

PAZIN, Rosina Alice. Indexação de multimeios. 2. ed. Curitiba: UFPR, 1993.

PEIRCE, Charles. S. Semiótica. São Paulo: Perspectiva, 1990

PEROTA, Maria Luiza Loures Rocha. Multimeios: seleção, aquisição, processamento, armazenagem, empréstimo. 4. ed. Vitória: Edufes, 1997.

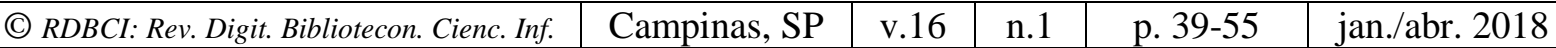


PIEDADE, Maria Antonieta Requião. Introdução à teoria da classificação. 2. ed. Rio de Janeiro: Interciência, 1983.

PINTO, Virginia Bentes.; MEUNIER, Jean-Guy.; NETO, Casemiro Silva. A contribuição peirciana para a representação indexal de imagens visuais. Encontros Bibli: revista eletrônica de biblioteconomia e ciência da informação, v. 13, n. 25, p. 15-35. 2008. Disponível em: < https://periodicos.ufsc.br/index.php/eb/article/view/15182924.2008v13n25p15/878>. Acesso em: 07 jun. 2017.

PINTO MOLINA, María. Análisis documental: fundamentos y procedimientos. 2. ed. Madrid: EUDEMA, 1993.

SANTAELLA, Lucia. Matrizes da linguagem e pensamento: sonora, visual, verbal. 3. ed. São Paulo: Iluminuras, 2005.

SANTAELLA, L.; NÖTH, Winfried. Imagem: cognição, semiótica, mídia. 6. ed. São Paulo: Iluminuras, 2013.

SHATFORD LAYNE, Sara. Sone issues in the indexing of images. Journal of the American Society for Information Science, v. 45, n. 8, p. 538-588, 1994. Disponível em: < http://polaris.gseis.ucla.edu/gleazer/462_readings/Layne_1994.pdf>. Acesso em: 30 jan. 2017.

SMIT, J. W. Análise documentária de documentos fotográficos. In: Silva, F. C. C. da; SALES, R. (Org.). Cenários da organização do conhecimento: linguagens documentárias em cena. Brasília: Thasaurus, 2011. Cap. 3, p. 265-286.
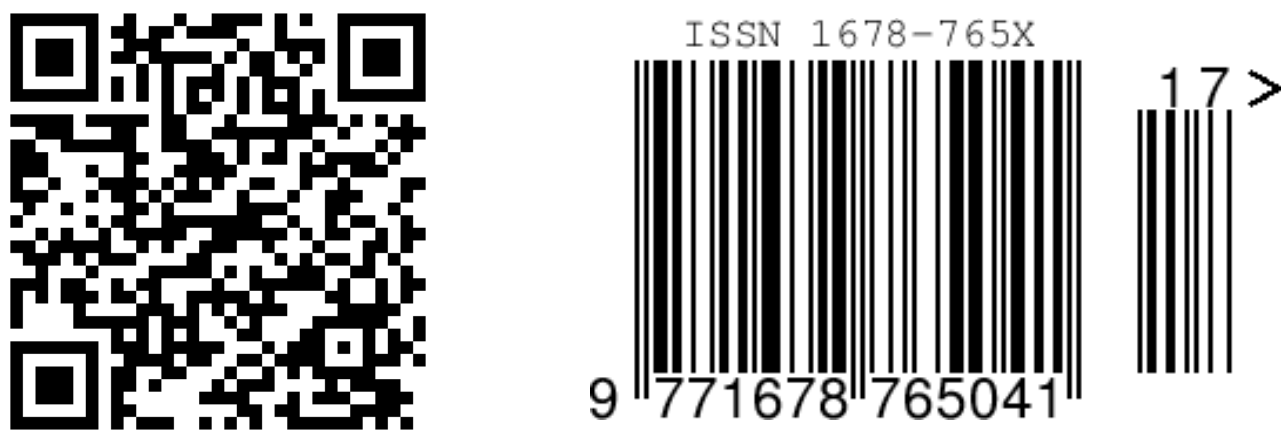